\title{
REASONS FOR TECHNOLOGY-BASED COMPANIES CONTEMPLATED BY THE FIRST COMPANY PROGRAM TO SEEK ISO 9001:2008 CERTIFICATION
}

\author{
Eduardo Gomes Salgado \\ Federal University of Alfenas, Brazil \\ E-mail: eduardosalgado@bcc.unifal-mg.edu.br
}

Carlos Eduardo Sanches da Silva Federal University of Itajubá, Brazil

E-mail: sanches@unifei.edu.br

Carlos Henrique Pereira Mello Federal University of Itajubá, Brazil E-mail: carlos.mello@unifei.edu.br

Submission: $14 / 10 / 2015$ Revision: 28/10/2015 Accept: 09/11/2015

\section{ABSTRACT}

The search for implementation of Quality Management Systems aims to continuously improve their results. Thus, for the services and/or products offered to convey trust and credibility, they must be designed within appropriate norms and standards. However, It was observed that companies have different challenges regarding the certification. Furthermore, the reasons for the implementation of ISO 9001 could be different between them. In this sense, this study seeks to assess the reasons that induce incubated technology-based companies to seek adequacy of their quality management system to the NBR ISO 9001:2008 standard. Through an exploratory survey in twenty-six incubated technology-based companies, a twelve-question questionnaire proposed by Bhuiyan and Alam (2005) was applied. After analyzing the data, it is concluded that the reasons for adequacy of QMS to the NBR ISO 9001:2008 standard are: competitive advantage over competitors; consultant's approach for implementation; improvement in product quality; and government 
funding for ISO 9001 certification. It is found that the consultant's approach stands out as a strong reason for seeking the adequacy of QMS to the NBR ISO 9001 standard.

Keywords: ISO 9001; Certification; Project; PRIME.

\section{INTRODUCTION}

A growing literature discusses and evaluates the capacity of financial support policies to increase private investment in R\&D through two main instruments: tax incentives (indirect support) and direct subsidies (direct support) (MONTMARTIN; HERRERA, 2015). Furthermore, the same authors assert that this topic is especially important in a context of public budget pressure that requires all public expenditure to be justified and effective. In this context, we can describe the Brazilian government actions.

The Brazilian government has developed several actions to reduce technological dependence and promote local and regional development (e.g. technology parks, business incubators, research incentive laws). This study addresses one of these incentives, the PRIME program developed by FINEP, which allocated investments of $R \$ 230,000,000.00$ in technology-based companies (TBC).

In Brazil, two thousand technology-based companies obtained $\mathrm{R} \$ 120.000,00$ to invest in market and management advisory services. The undertakings funded by FINEP started their projects in November 2009. Some companies, among the consulting firms hired, opted for certifying their Quality Management System in accordance with ISO 9001:2008, either by requirements of the market or their own initiative (SALGADO et al., 2014a).

To coordinate the PRIME program, 12 coordination centers were selected, one of them located in the South of Minas Gerais State with 66 companies covered by this program. The decision to adopt a quality management system (QMS) is a strategic decision, especially for small technology-based companies, because the QMS helps the company to obtain other certifications. Specifically for the companies' object of this study, some markets and customers require specific certifications: Software development companies (e.g. CMMI, MPS-BR; ISO/IEC 15504); manufacturing companies (e.g. automotive industry ISO TS 16949). 
Several research teams have sought to identify the reasons that motivate companies to implement ISO 9001 (PSOMAS; FOTOPOULOS, 2009; MAGD, 2008; TIAN; TAM, 2007; POKSINSKA; EKLUND; DAHLGAARD, 2006; BHUIYAN; ALAM, 2005; YAHYA; GOH, 2001). Those studies focused on large companies from several countries. Differently, Rouber et al (2014) have identified and analyzed the effects of the ISO 9001:2000 implementation process in a small Brazilian company in the printer supplies business. In this way, this study has the same focus, having as object of study incubated technology-based companies.

Based on the above, the following questions served as motivation for this research: what are the reasons for a Technology-Based company implement a QMS based on ISO 9001? The research method is the same used by studies similar to the exploratory survey (e.g. SALGADO, et al. 2014a; FERREIRA, et al. 2015). It has as hypothesis:

- $\mathrm{H} 1$ : the reasons for implementing QMS based on the NBR ISO 9001: 2008 standard identified by the work of Bhuiyan and Alam (2005) are the same as those of technology-based companies in the South of Minas Gerais contemplated by the PRIME program that allocated resources in certification projects;

- $\mathrm{H} 2$ : the age of the company is related to the implementation reasons;

- H3: the implementation percentage of the project is related to the implementation reasons.

This paper aims to identify the reasons that TBC had to implement their Quality Management System in accordance with ISO 9001:2008. The study was conducted in three stages. The first consisted of a literature review on the TBC and the quality management system - ISO 9001. This stage has been proved as of great importance to the implementation of a QMS, as well as the importance of the TBC in the national economy.

In the second stage, a survey was carried out on technology-based companies in the South of Minas Gerais contemplated by the PRIME program that allocated resources in certification projects, which could participate in the field-research. Besides that, the questionnaire of Bhuiyan and Alam (2004) was chosen to perform 
DOI: 10.14807/ijmp.v7i1.387

the data collection. In the third stage, the compilation and analysis of data was performed.

\section{LITERATURE REVIEW}

\subsection{ISO 9001}

The interest in ISO 9001 certification is growing. It is no longer a privilege of multinational and large companies, but increasingly, micro, small and medium companies have achieved certification (ALDOWAISAN; YOUSSEF, 2006). Much of this search for certification is due to client demands, making it a mandatory requirement for many companies to become a supplier (GÓMEZ, et al, 2009). In addition, Gómez et al (2009) state that ISO 9001 is, among the models of the QMS, the most influential and most implemented standard. The adoption of a QMS should be a strategic decision (MELLO; SALGADO; SILVA, 2005; PISKAR; DOLINSEK, 2006; HERAS; CILLERUELO; IRADI, 2008).

With the growth of ISO 9001, several researchers approached the subject as object of study. The topics are diverse, such as: reasons, benefits, obstacles, partnerships, leaderships, concerns, tools, techniques, fears, difficulties, implementation systematic, obligations in the implementation of a QMS, financial performance in various sectors of activity such as: Staines (2000), Pascal, Chalochet and Damour (2002), Bhuiyan and Alam (2004), Bhuiyan and Alam (2005), van der Heuvel, Koning, Bogers, Berg, van Dijen (2005), Poksinska, Eklund, Dahlgaard (2006), Aggelogiannopoulos, Drosinos and Athanasopoulos (2007), Fotopoulos and Psomas (2008), Jovanovic and Jovanovic (2008), Benner and Veloso (2008), Sampaio, Saraiva and Rodrigues (2009), Kirsch, Vogg, Hosten and Fleba (2009).

This study is based on Bhuiyan and Alan's article (2005) which provided its research protocol, identifying the reasons for certification of a quality management system as described in Table 1.

Storey and Tether (1998) on researching articles from different countries, say that each country defines technology-based company differently. According to Dahlstrand (2007), defining technology-based company is a complex task because the parameters for such classification are relative, since the measurement of a technology does not admit single answers. To that end, they seek to identify 
technology conceptions of "traditional" and "advanced", "breakthrough" or "emerging" bases.

Table 1 - Qualitative research versus quantitative research

\section{Reasons to seek ISO 9001 certification}

1 - Customer requirements/expectations

2 - Competitive pressure from competitors

3- Competitive advantage over competitors

4 - Aid to export-related activities

5 - Potential access to export market

6 - Consultants' approach for implementation

7 - Government procurement policy (item required in biddings)

8 - Improvement in product quality;

9 - Improvement in quality management practices

10 - Culture / discipline the organization

11 - Government funding for ISO 9001 certification

12- Meet all necessary legislation for the marketing of products (e.g. ANVISA)

\subsection{Technology-Based Company}

Technology-Based Company is focus of many researches such as Lindelöf and Löfsten (2003), $\mathrm{Ng}$ (2006) as Salgado et al. (2014b). In this paper, the term Technology-Based Company is based on the definition proposed by The National Association of Entities Promoting Innovative Enterprises (HENCE; ANPROTEC, 2002).

Hence and Anprotec (2002) defines technology-based company as one that has a process or product that results from scientific research and whose added value comes from advanced technology areas such as: information technology, biotechnology, fine chemicals, precision mechanics, new materials etc., and can even be characterized by the application of scientific knowledge, the mastery of complex techniques and the high technical qualification work.

Countries considered of global economy recognize the loss of advantages in traditional industries and have shifted their focus, including policy and support to emerging industries. These industries have their basis in knowledge and innovation activities, developing products and services that generate high levels of aggregated and social outcomes (MOHANNAK, 2007).

According to $\mathrm{Ng}$ (2006), technology-based enterprises as a matter of study object is justified, since they explore technologies with a continuous development focusing on profits due to launching of new products, services and solutions with a 
DOI: 10.14807/ijmp.v7i1.387

high aggregated-value to the final client. This whole process just mentioned does not happen in the same way for traditional industries. On the same line, Lindelöf and Löfsten (2003) claim that technology-based enterprises' role is to accelerate the technology propagation and to enhance the enterprise competitiveness.

\section{RESEARCH METHOD}

The survey research, according to Fink and Kosecoff (1998) and Forza (2002), is a method of collecting information directly from people about their ideas, feelings, health, plans, beliefs and, social, educational and financial background, or about the unit, company or organization they operate. According to Pinsonneault and Kraemer (1993), the Survey research can be classified as to their purpose in explanatory, exploratory or descriptive. Based on the classification proposed by Pinsonneault \& Kraemer (1993), as to the purpose, this research is exploratory due to its goal. This research used steps proposed by Pinsonneault and Kraemer (1993), Fink (1995) and Forza (2002):

- Defining the purpose of the research

- Population and Sample: Incubators of the Mineira Innovation Network

- Implementation Method

- Preparation of the instrument

- Validation of the instrument

- Data Collection

- Preliminary analysis of the data

The questionnaire was prepared in accordance with factors, processes, variables and scales to identify the reasons for implementing ISO 9001. We used the questionnaire elaborated by Bhuiyan and Alan (2005); see Table 1, which is based on a Likert scale. The respondents assigned a single response to each reason, with five options to choose from, varying the intensity from very much (5) to none (1). The opinions were collected from partners of the companies, which were the ones in charge for the allocation of PRIME resources into advisory projects. A question regarding the company's business segment was added to the questionnaire: 1 manufacturing; 2 - hospital doctor; 3 - Software; 4 - services.

The survey on Technology-Based Companies was conducted for 20 days in November 2010, and the contact was established through electronic mail (e-mail), 
DOI: 10.14807/ijmp.v7i1.387

interviews and phone calls. The first step was to validate the questionnaire used, so that the information obtained from respondents corresponded to reality, even though it was their personal opinions.

To assess whether a questionnaire has reliable variables, an internal validation can be used, which refers to how well the instrument measures what it is proposed to measure; and an external validation to infer a possible situation in the population, and if the results are generalizable, according to Giuffre (1997a, 1997b).

The sample for this study was defined as all the companies covered by the PRIME program in the southern region of Minas Gerais, which have developed adequacy projects of their Quality Management System to the standard ISO 9001: 2008. A total of 34 companies (51\%) allocated PRIME resources aiming adequacy of their QMS with focus on ISO 9001, of which 26 (76\%) completed the questionnaire. It is worth noting that all companies started the project at the same time due to requirements.

To determine the reliability of the questionnaire, the degree of homogeneity of the set of responses was calculated using Cronbach's alpha, since it provides internal consistency values, enabling the evaluation of the scale used (HAIR JR. et al., 2005).

Internal validity indicates the instrument's application conditions, in this case the questionnaire. While there is no absolute standard, Cronbach's alpha values equal to or above 0.70 reflect an acceptable reliability (NUNNALY; BERNSTEIN, 1994; HAIR JR.; et al. 2005).

However, Malhotra (2006) recommends, as a decision criterion for "Cronbach's alpha to be considered acceptable, indices above 0.6; and the closer to 1 , greater the reliability". In this work, Cronbach's alpha was calculated using the software Minitab $15 \circledast$. The lowest value found was 0.9498 , which can be considered acceptable.

In this paper, we used the "Partial Least Squares" regression method or PLS that applies when there are: multiple dependent variables, highly correlated predictors, and more predictors than observations, according to Yacoub and MacGregor (2003), Helland (1988). The PLS method reduces the number of predictors to a set of principal components. Therefore, PLS is a method that seeks to 
DOI: 10.14807/ijmp.v7i1.387

form components that capture the maximum information of the variables $X$ and that is useful for predicting $\mathrm{Yi}$, while reducing the dimensionality of the regression problem by using a smaller number of components than original variables.

The correlation analysis using PLS, calculated through the software Minitab 15 $®$, uses the algorithm NIPALS (Nonlinear Iterative Partial Least Squares). The NIPALS is an extension of PLS used for multivariate data analysis. As in PLS, the NIPALS is used in cases where all dependent variables are provided simultaneously, according to Sena and Poppi (2004).

The PLS model and a waste analysis were performed to verify their normality. In case of abnormality of the waste, you eliminate its generating element and recalculate the model. The process is repeated until normality of the wastes is obtained and only then the analysis of the PLS results is performed. Data normality was obtained in the waste analysis.

One major issue that arises in the Principal Component Analysis is the criterion for choosing the number of components to retain. Kim and Mueller (1978) report that the most popular methods are: Kaiser, which proposes to consider only the eigenvalues greater than one, demonstrating that these values would be statistically significant.

But this condition is not sufficient. Not all eigenvalues greater than one correspond to components with apparent significance; and the Eigenvalues Diagram: which consists of observing the diagram of eigenvalues and retaining the ones situated above the breakpoint of the fall of the curve of the function that relates the order and the eigenvalues.

Thus, if two factors are associated with almost equal eigenvalues, they represent the same proportion of variability and there is no reason, a priori, to keep one and not the other. However, a strong decrease between two successive eigenvalues follows in conserving the predecessor factors in the interpretation.

According to Babbie (2005), one deemed adequate response rate is $50 \%$, a rate of $60 \%$ is considered good, and a rate of $70 \%$ or more is considered very good. The author believes that these rates have no statistical basis and that honesty in the answers have a much greater importance that a high response rate. 
DOI: 10.14807/ijmp.v7i1.387

As we obtained $76 \%$ of responses, by the managing partners, the questionnaire was applied in person and $100 \%$ of the questionnaires were validated, the external validity is considered appropriate. After data collection, statistical analyzes were performed on the number of employees and in relation to the time to get certified. For both data (time to obtain and number of employees), it was performed waste analyzes, number of principal components, variance analysis, determination of factors and alpha Cronbach.

\section{RESULTS AND DISCUSSIONS}

Data box plot was carried out (Figure 1 and 2), and the outliers kept in subsequent analyzes. In addition, Figure 3 presents the Market Segment of the companies that participated in the Survey

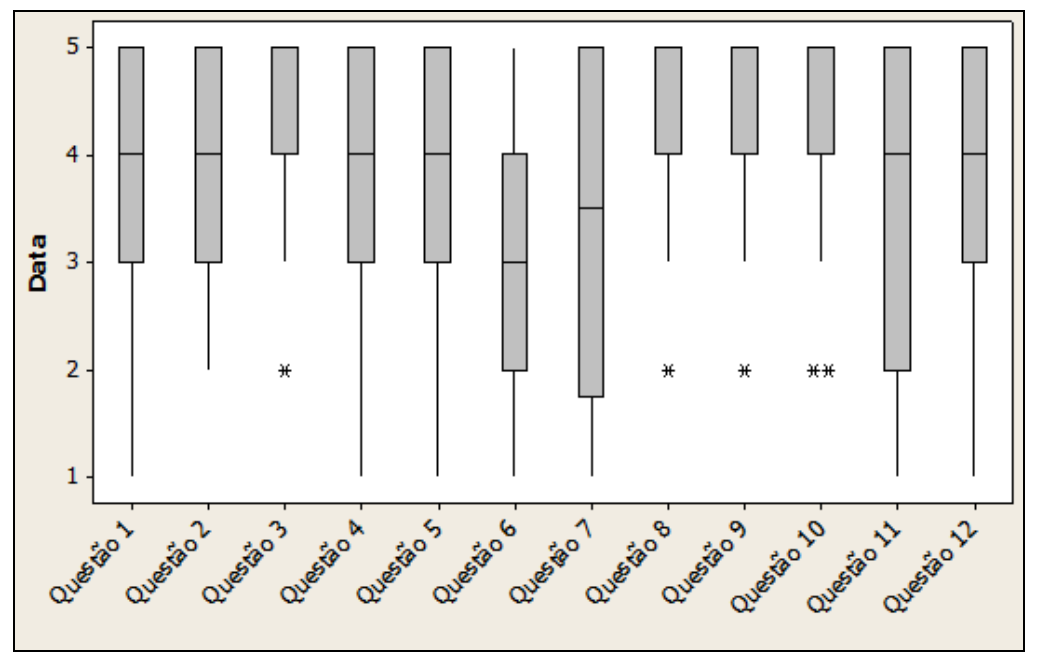

FIGURE 1: Box Plot of the opinions on reasons for implementation.



FIGURE 2: Box Plot of the company's age and the \% of implementation of the QMS adequacy project to NBR ISO 9001: 2008. 


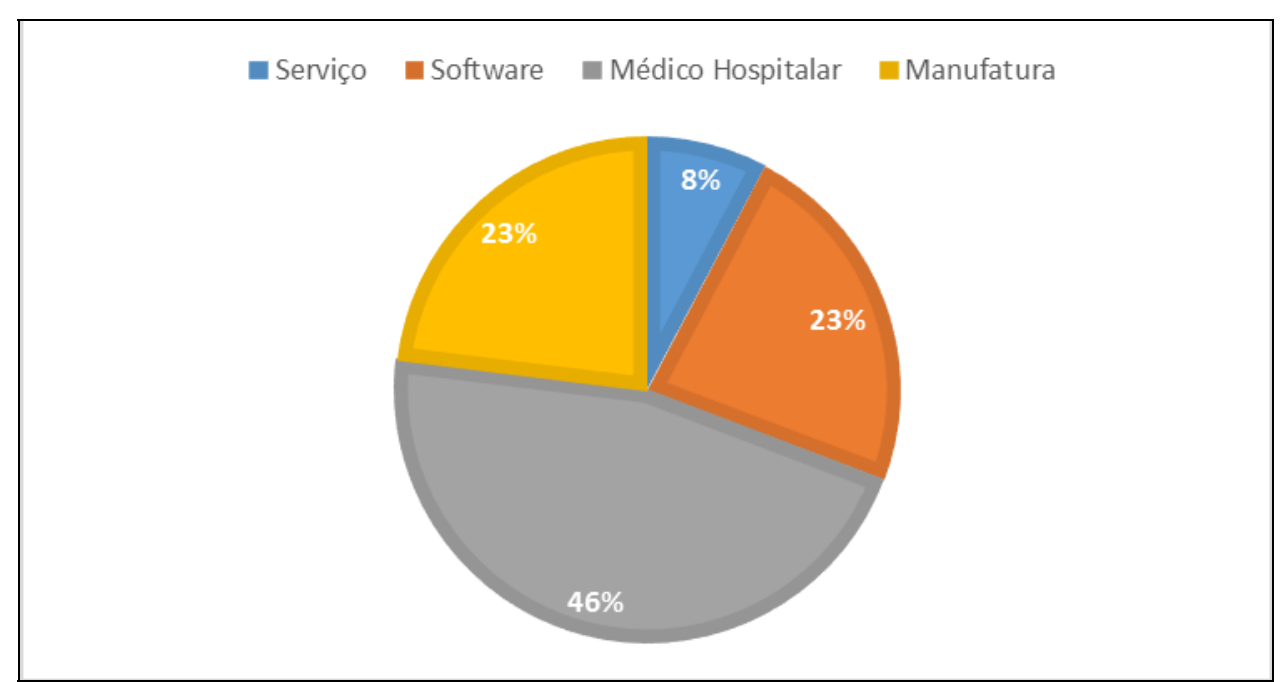

Figure 3: Market Segment of the companies that participated in the Survey.

There is great dispersion in the implementation reasons (Figure 1). In Figure 2, the median age of the companies is 19.5 months, the minimum 5 months and the maximum 42 months. For the percentage implemented, the median is $72 \%$, the maximum $90 \%$ and the minimum $51 \%$; it turns out that none of the companies completed the project within the deadline established by PRIME (12 months). Subsequently, the $T$ test (Table 2 ) in the Minitab15 $®$ software for the perception of difficulties in the implementation of the section, considering a statistical difference of $5 \%$ ( $p$-value lower or equal to 0.05 ). The statistically significant reasons (H1) are described in Table 3.

Table 2: T Test reasons to implement NBR ISO 9001: 2008

\begin{tabular}{cccccccc}
\hline Variable & $\boldsymbol{N}$ & Mean & StDev & SE Mean & $\mathbf{9 5 \%} \mathbf{C l}$ & $\boldsymbol{T}$ & $\boldsymbol{P}$ \\
\hline Question 1 & 26 & 3,769 & 1,366 & 0,268 & $(3,218 ; 4,321)$ & $-0,86$ & 0,397 \\
\hline Question 2 & 26 & 3,769 & 0,992 & 0,195 & $(3,368 ; 4,170)$ & $-1,19$ & 0,247 \\
\hline Question 3 & 26 & 4,577 & 0,758 & 0,149 & $(4,271 ; 4,883)$ & 3,88 & 0,001 \\
\hline Question 4 & 26 & 3,808 & 1,327 & 0,260 & $(3,272 ; 4,344)$ & $-0,74$ & 0,467 \\
\hline Question 5 & 26 & 3,615 & 1,203 & 0,236 & $(3,130 ; 4,101)$ & $-1,63$ & 0,115 \\
\hline Question 6 & 26 & 2,846 & 1,255 & 0,246 & $(2,339 ; 3,353)$ & $-4,69$ & 0,000 \\
\hline Question 7 & 26 & 3,308 & 1,543 & 0,303 & $(2,684 ; 3,931)$ & $-2,29$ & 0,031 \\
\hline Question 8 & 26 & 4,500 & 0,762 & 0,149 & $(4,192 ; 4,808)$ & 3,35 & 0,003 \\
\hline Question 9 & 26 & 4,462 & 0,811 & 0,159 & $(4,134 ; 4,789)$ & 2,90 & 0,008 \\
\hline Question 10 & 26 & 4,385 & 0,983 & 0,193 & $(3,988 ; 4,782)$ & 2,00 & 0,057 \\
\hline Question 11 & 26 & 3,385 & 1,444 & 0,283 & $(2,801 ; 3,968)$ & $-2,17$ & 0,040 \\
\hline Question 12 & 26 & 3,385 & 1,211 & 0,237 & $(3,396 ; 4,374)$ & $-0,49$ & 0,631 \\
\hline
\end{tabular}


DOI: 10.14807/ijmp.v7i1.387

Table 3: Statistically Significant ISO 9001 Implementation Reasons - (T Test)

\begin{tabular}{|c|c|c|}
\hline $\begin{array}{l}\text { Bhuiyan and Alam } \\
\qquad(2005)\end{array}$ & $\begin{array}{l}\text { Technology-based } \\
\text { companies in the South } \\
\text { of Minas Gerais } \\
\text { contemplated by PRIME } \\
\text { that allocated resources } \\
\text { in a certification } \\
\text { projects }\end{array}$ & Comments \\
\hline $\begin{array}{l}1 \text { - Customer } \\
\text { requirements/ } \\
\text { expectations }\end{array}$ & $\begin{array}{l}6 \text { - Consultants' approach } \\
\text { for implementation }\end{array}$ & $\begin{array}{l}\text { The technology-based companies are mostly } \\
\text { incubated }(88 \%) \text {, still in the development phase } \\
\text { of their products, so there are no customer } \\
\text { requirements. In addition to being influenced } \\
\text { by the consultants. }\end{array}$ \\
\hline $\begin{array}{l}\text { 3- Competitive } \\
\text { advantage over } \\
\text { competitors }\end{array}$ & $\begin{array}{l}\text { 3- Competitive advantage } \\
\text { over competitors }\end{array}$ & $\begin{array}{l}\text { Coincident between the surveys, prevailing an } \\
\text { external perspective (market) }\end{array}$ \\
\hline $\begin{array}{l}8-\text { Improvement in } \\
\text { product quality }\end{array}$ & $\begin{array}{l}8-\text { Improvement in } \\
\text { product quality }\end{array}$ & $\begin{array}{l}\text { Coincident between the surveys, prevailing an } \\
\text { external perspective (market) }\end{array}$ \\
\hline $\begin{array}{l}9 \text { - Improvement in } \\
\text { quality management } \\
\text { practices }\end{array}$ & 11 - Government funding & $\begin{array}{l}\text { The motivation for hiring assistance to conform } \\
\text { the QMS to the NBR ISO } 9001: 2008 \text { standard } \\
\text { was the resources allocated by the PRIME } \\
\text { project. As most technology-based companies } \\
\text { are in their product development phase and just } \\
\text { beginning the production process, there are few } \\
\text { needs of improvements in quality practices. }\end{array}$ \\
\hline $\begin{array}{l}10 \text { - Culture / } \\
\text { discipline the } \\
\text { organization }\end{array}$ & & $\begin{array}{l}\text { The technology-based companies are young, } \\
\text { on average } 19.5 \text { months old, still in the } \\
\text { development phase of their products and } \\
\text { creation of their culture. }\end{array}$ \\
\hline
\end{tabular}

The comments were obtained from the managing partners of the companies through semi-structured interviews.

Subsequently, It was used the method of regression "Partial Least Squares" or PLS that applies when there are: multiple dependent variables, highly correlated predictors; more predictors than observations (YACOUB; MACGREGOR, 2004; HELLAND, 1988).

The PLS method reduces the number of predictors to a set of major components. Therefore, PLS is a method which seeks to form components that capture the maximum information from the variables $X$ and that is useful for predicting $\mathrm{Yi}$, while reducing the dimensionality of the regression problem by using a smaller number of components than original variables (SILVA, 2009).

In this research, there are 12 reasons for implementing NBR ISO 9001:2008 $(\mathrm{X})$, and it was identified that they are correlated, besides the existence of more predictors than observations ( 20 variable $\mathrm{X}$ questions against $2 \mathrm{Yi}$ : company age and percentage of the certification project developed). 
DOI: 10.14807/ijmp.v7i1.387

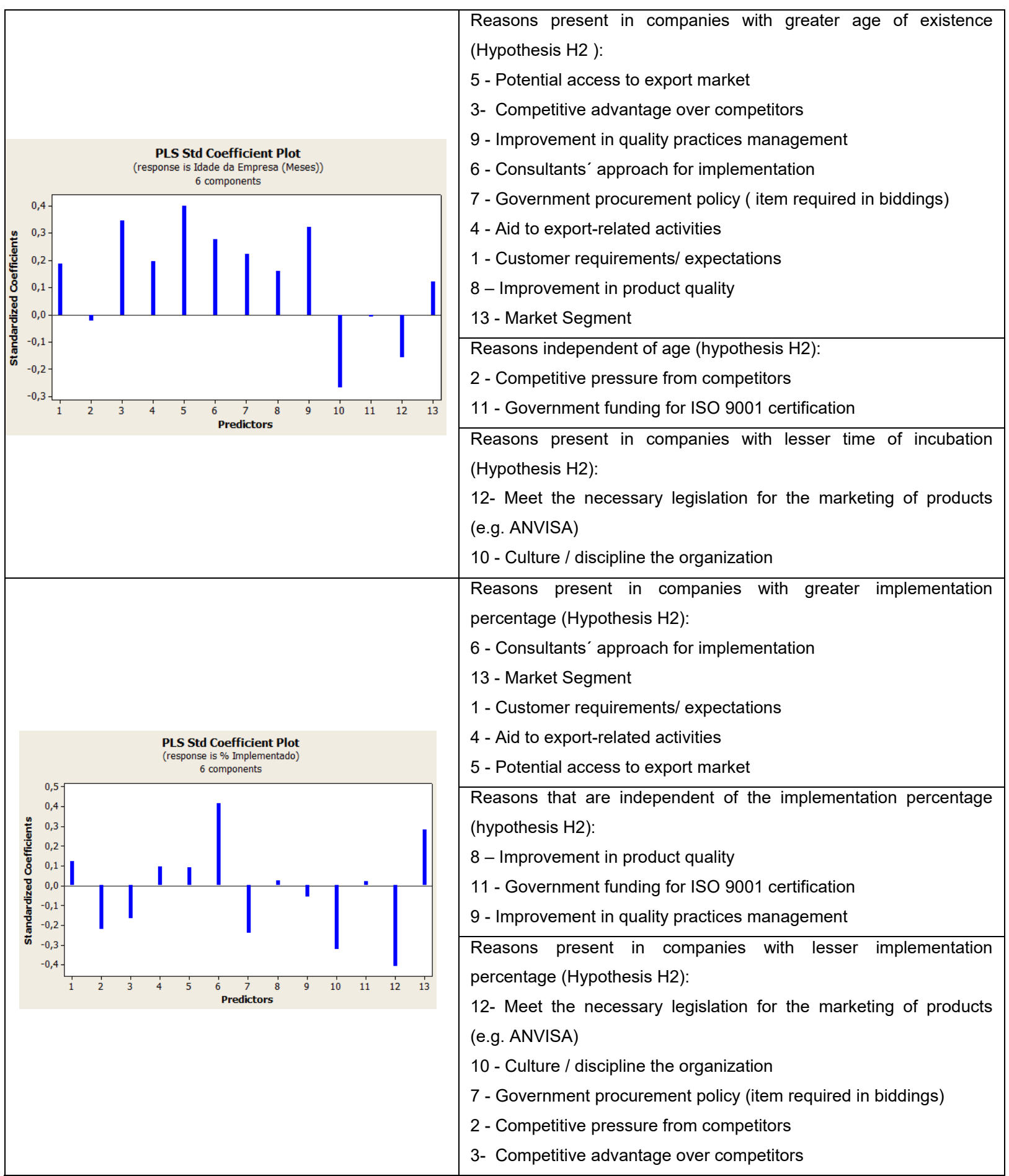

Figure 4: Reasons to implement a QMS according to the NBR ISO 9001:2008 standard and the value of their respective PLS coefficient for the results analyzed.

The correlation analysis uses the PLS, calculated through the software Minitab $15 \AA$, that according to Silva (2009), uses the algorithm NIPALS (Nonlinear Iterative Partial Least Squares). All the results showed relation with the age of the company and the percentage of the certification project implemented for a confidence interval of $95 \%$ (Pvalue $<0.05$ ), obtaining for both values of PValue: 0,000 . The waste analysis resulted in the normality of the data. 
DOI: 10.14807/ijmp.v7i1.387

One major issue that arises in the Major Component Analysis is the criterion for choosing the number of components to retain. It was based on the eigenvalues diagram considering the ones situated above the breakpoint of the curve fall of the function that lists the order and the eigenvalues (KIM; MUELLER, 1978). Six major components were considered for both results.

Reasons to implement QMS according to the NBR ISO 2008:5 standard and the value of their respective PLS coefficient for the results analyzed (Figure 4).

Analyzing Figure 4, we identified that the reasons present in companies with greater age and percentage of implementation of the NBR ISO 9001:2008 project are: 6 - Consultants' approach for implementation; 13 - Market Segment; 1 Customer requirements/ expectations; 4 - Aid to export-related activities; 5 - Potential access to export market.

Meanwhile, the reasons for companies with lesser age and a lower percentage of project implementation are: 12 - Meet the necessary legislation for the marketing of products (e.g. ANVISA) and 10 - Culture / discipline the organization Note that reason 12 - Government funding for ISO 9001 certification is a reason that is independent of the company's age and the percentage of the QMS adequacy project implemented.

The following comments were obtained when presenting the results to some managing partners participating in the research:

“... incubated companies that have been around for some time are starting the commercialization of their products, they are closer to the market and therefore more engaged in the implementation of the QMS. It was expected the reasons to be common: market segment; customer requirements/expectations; aid to export-related activities; and potential access to export market."

"... the influence of the consultant in selling us advice was for sure a major reason for us to buy their services."

"... many companies have not progressed in the implementation of their QMS. The main cause was that the company's efforts were focused on product development; first comes the product that is the generator of revenues."

"... we had to spend the resources provided by PRIME ...." 
DOI: 10.14807/ijmp.v7i1.387

A cluster analysis (Figure 5), performed in the Minitab $15 \AA$ software, allows you to identify that the questions 4 (aid to export-related activities) and 5 (potential access to export markets) can be grouped together because they have a similarity level of $92.25 \%$.

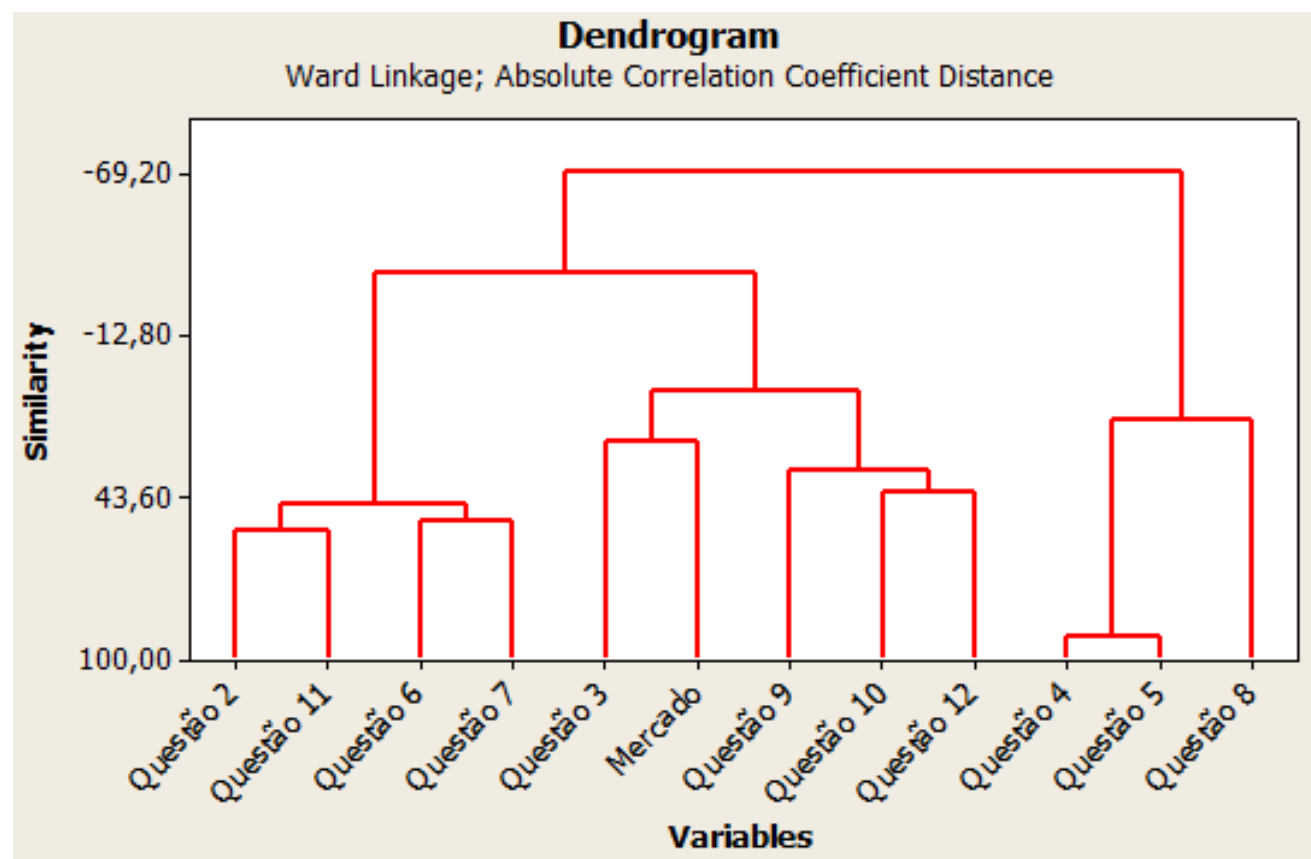

Figure 5: Dendrogram of the reasons that lead companies to seek adequacy of their QMS to the NBR ISO 9001: 2008 standard.

\section{CONCLUSIONS}

The reasons for technology-based companies in the South of Minas Gerais contemplated by the PRIME program have allocated resources in a certification project their QMS to the NBR ISO 9001: 2008 standard are: 3 - Competitive advantage over competitors; 6 - Consultants' approach for implementation; 8 Improvement in product quality; and 11 - Government funding for ISO 9001 certification. It is found that among these reasons, three are of external origin and only one internal.

Regardless of the age of the company or the implementation percentage of the QMS adequacy project, the consultant stands out as a strong reason for searching adequacy of their QMS. In this sense, the criteria for selecting consulting firms, as well as guidelines provided by funding bodies proved to be object of special attention.

The market segment in which the company operates has influence in the search for adequacy to the NBR ISO 9001:2008 standard. 
DOI: 10.14807/ijmp.v7i1.387

\subsection{Managerial Implications}

The results here stated provide managers, practitioners and researchers new information's to support their decision to implement a ISO 9001 taking into account the better understanding about the reasons for certification. Moreover, this research has identified the main reasons for Technology-Based Companies implement the ISO 9001. In addition, these results can support certification bodies and consultancy firms to demonstrate for the customers the point of view for the specialist.

\subsection{Future Research}

It has become apparent during this paper that many studies have been carried out with focus on identify the reasons, benefits and difficulties to implement ISO 9001. However, it is possible to suggest future research:

- First, increasing the number of companies participating in the PRIME project, so that the companies can be analyzed in a stratified way for the market segment.

- Also, considering that the Technology-Based companies certificated were not part of the scope of this research, a survey including them would be interesting.

- Finally, due to the ISO 9001 standard revision, the current research should be performed in the future in order to analyze the impact of the revision process in the reason, difficulties and benefits.

\section{ACKNOWLEDGEMENTS}

The authors would like to thank the CAPES Foundation, (Process PE024/2008), the FAPEMIG Foundation (Processes: APQ-00976-13, TEC-PPM00520/13 and TEC-PPM-00058-13) and the CNPq (Processes: 249160/2013-7, $310660 / 2012-2,401082 / 2014-8$ and $478509 / 2012-0$ ), that without their support, this work would be impossible. In addition, the authors thank the interviewees, by their information, patience and devoted time for this work.

\section{REFERENCES}

AGGELOGIANNOPOULOS, D.; DROSINOS, E. H.; ATHANASOPOULOS, P. (2007) Implementation of a quality management system (QMS) according to the ISO 9000 
family in a Greek small-sized winery: A case study. Food Control. v. 18, n. 9, p. 1077-1085.

ALDOWAISAN, T. A.; YOUSSEF, A. S. (2006) An ISO 9001:2000-based framework for realizing quality in small businesses. Omega. v. 34, n. 3, p. 231-235.

ALMUS, M.; NERLINGER, E. A. (1999) Growth of New Technology-Based Firms: Which Factors Matter? Small Business Economics. v. 13, n. 2, p.141-154.

ANPROTEC. Associação Nacional de Entidades Promotoras de Empreendimentos de Tecnologias Avançadas. (2002) Glossário dinâmico de termos na área de Tecnópolis, Parques Tecnológicos e Incubadoras de Empresas. Brasília/DF, Editado Anprotec \& Sebrae.

ASSOCIAÇÃO BRASILEIRA DE NORMAS TÉCNICAS - ABNT (2008) NBR ISO 9001. Sistemas de gestão da qualidade - requisitos. ABNT, Rio de Janeiro, Dezembro.

BADE, F. J.; NERLINGER, E. A. (2000) The spatial distribution of new technologybased firms: Empirical results for West-Germany. Papers in Regional Science. v. 79, n. 2, p. 155-176.

BENNER, M.; VELOSO, F. M. (2008) ISO 9000 practices and financial performance: A technology coherence perspective. Journal of Operations Management. v. 26, n. 5, p. 611-629.

BHUIYAN, N.; ALAM, N. (2004) ISO 9001:2000 Implementation - The North American Experience. Intenational Journal of Productivity and Performance Management. v. 53, n. 1, p. 10-17.

BURNETT, L.; ROCHESTER, C.; MACKAY, M.; PROOS, A.; SHAW, W.; HEGEDUS, G. (1997) Implementation of ISO 9001 in a medical testing laboratory. Journal for Quality, Comparability and Reliability in Chemical. v. 2, n 2, p. 76-81.

FERREIRA, C. S.; SALGADO, E. G.; SILVA, C. E. S.; MELLO, C. H. P.; SAMPAIO, P. (2015) Reasons and benefits associated with ISO 9001 certification for sugar and ethanol companies. Independent Journal of Management \& Production, v. 6 n. 3, p. 623-642.

FINK, A.; KOSECOFF, J. (1998) How to conduct surveys - a step-by-step guide. 2a. Ed., Thousand Oaks, California, Sage Publications.

FORZA, C. (2002) Survey research in operations management: a process-based perspective. International Journal of Operations \& Production Management. v. 22, n. 2, p. 152-194.

GIUDICI, G.; PALEAR, S. (2000) The Provision of Finance to Innovation: A Survey Conducted among Italian Technology-based Small Firms. Small Business Economics. v. 14, n. 1, p. 37-53.

GÓMEZ, B.; PLACERES, M.; LÓPEZ, Y.; DOMÍNGUEZ, P. (2009) Certification of investigacional medicinal products management according to normative ISO 9001:2000in a hospital pharmacy service. Medicina Clinica. v. 133, n.12, p. 479485.

GOTZAMANI, K. D.; TSIOTRAS, G. D.; NICOLAOU, M.; NICOLAIDES, A.; HADJIADAMOU, V. (2007) The contribution to excellence of ISO 9001: the case of certified organisations in Cyprus. The TQM Magazine. v. 19, n. 5, p. 388-402. 
HERAS, I.; CILLERUELO, E.; IRADI, J. (2008) ISO 9001 and residential homes for the elderly: a Delphi study. Managing Service Quality. v. 18, n. 3, p. 272-288.

HEUVEL, J. V. D.; KONING, L.; BOGERS, A. J. J. C.; BERG, M.; DIJEN, M. E. M. (2005) An ISO 9001 Quality Management Sustem in a Hospital - Bureaucracy or Just Benefits?. Intenational Journal of Productivity and Performance Management. v. 18, n. 4-5, p. 361-369.

HEYDEBRECK, P.; KLOFSTEN, M.; MAIER, J. C. (2000) Innovation support for new technology-based firms: the Swedish Teknopol approach. R\&D Management. v. 30, n.1, p. 89-100.

IWASAKI, S.; TONE, K. (1998) A search model with subjective judgments: Auditing of incorrect tax declarations. Omega - International Journal of Management Science. v. 26, n.2, p. 249-261.

JOVANOVIC, M.; JOVANOVIC, J. (2008) Implementation of a quality management system in meteorological practice in Serbia. Accreditation and Quality Assurance. v. 13, n. 1, p. $47-52$.

JUCÁ JUNIOR, A. S. (2005) Gestão de projetos em empresas de base tecnológica da área de software: análise do nível de maturidade e aplicabilidade de escritórios de projetos. Dissertação de Mestrado. Universidade de São Paulo. São Carlos/SP.

KIRSCH, M.; VOGG, I.; HOSTEN, N.; FLEßA, S. (2009) Quality management in a radiological practice. Experiences with a certification for DIN EN ISO 9001:2000. European Journal of Radiology, v. 75, n. 1, p. e1-8.

KIRWAN, P.; SIJDE, P. V.;GROEN, A. (2006) Assessing the needs of new technology based firms (NTBFs): An investigation among spin-off companies from six European Universities. The International Entrepreneurship and Management Journal. v. 2, n. 2, p. 173-187.

LINDELÖF, P.; LÖFSTEN, H. (2003) Science Park Location and New TechnologyBased Firms in Sweden - Implications for Strategy and Performance. Small Business Economics, v. 20, n. 3, p. 245-258.

MARTÍNEZ-PARDO, M. E.; MARIANO-MAGAN, D. (2008) The tissue bank at the Instituto Nacional de Investigaciones Nucleares: ISO 9001:2000 certification of its quality management system. Cell Tissue Banking. v. 8, n. 3, p. 221-231.

MONTMARTIN, B.; HERRERA, M. (2015) Internal and external effects of R\&D subsidies and fiscal incentives: Empirical evidence using spatial dynamic panel models. Research Policy, v. 44, n. 5, p. 1065-1079.

MINISTÉRIO DE CIÊNCIA E TECNOLOGIA (MCT). (2010) Manual para a Implantação de Incubadoras de Empresas. Brasília. 33 p., 2000. Disponível em: < http://www.mct.gov.br/>. Acesso: 09 fev.

MELLO, C. H. P.; SALGADO, E. G.; SILVA, C. E. S. (2005) A contribuição do gerenciamento de projetos na implantação de Sistema de Gestão da Qualidade. XII Simpósio de Engenharia de Produção - SIMPEP, Bauru/SP.

MENDES, G. H. S.; TOLEDO, J. C. (2005) Gestão do processo de desenvolvimento de produto em empresas de base tecnológica de pequeno porte: casos no setor de equipamentos médico-hospitalares. V CBGDP, Curitiba/PR. 
MOHANNAK, K. (2007) Innovation networks and capability building in the Australian high-technology SMEs. European Journal of Innovation Management. v. 10, n. 2, p. 236-251.

NG, A. W. (2006) Reporting intellectual capital flow in technology-based companies: Case studies of Canadian wireless technology companies. Journal of Intellectual Capital, v. 7, n. 4, p. 492-510.

PARTOVI, F. Y. (2007) An analytical model of process choice in the chemical industry. International Journal of Production Economics, v. 105, n.1, p. 213-227.

PASCAL, P.; CHALOCHET, A.; DAMOUR, O. (2002) ISO 9001 Certification of a Hospital Cornea Bank. Intenational Journal of health Care Quality Assurance, v. 15, n.4, p. 172-178.

POKISINSKA, B.; EKLUND, J. A. E.; DAHLGAARD, J. J. (2006) ISO 9001:2000 in a Small Organisations - Lost Opportunities, Benefits and Influencing Factors.

Intenational Journal of Productivity and Performance Management, v. 26, n. 5, p. 490-512.

PSOMAS, E. L.; FOTOPOULOS, C. V. (2009) A meta analysis of ISO 9001:2000 research - findings and future research proposals. International Journal of Quality and Service Sciences. v. 1, n. 2, p. 128-144.

ROBERTO FILHO, J. (2008) Gestão de manutenção em manufatura: Aplicação da teoria da decisão baseada em conceitos de confiabilidade. Dissertação de Mestrado Profissional, Engenharia Automotiva, Universidade de São Paulo, São Paulo/SP.

ROUBER, J. S.; BORGES, M. A. V.; MANUEL JÚNIOR, M. L.; PACHECO, D. A. J. (2014) A critical analysis of quality managment implementation in a small brazilian company. Independent Journal of Management \& Production, v. 5, n. 2, p. 398416.

SALGADO, E. G.; SILVA, C. E. S.; MELLO, C. H. P.; SILVA, E. R. S. (2014a) Difficulties encountered in ISO 9001:2008 implementation projects in Incubated technology-based Companies. International Journal of Quality Research, v. 8, n. 3, p. 357-369.

SALGADO, E. G.; SALOMON, V. A. P.; MELLO, C. H. P.; SILVA, C. E. S. (2014b) A Reference Model for the New Product Development in Medium-Sized Technology Based Electronics Enterprises. IEEE Latin America Transactions, v. 12, n. 8, p. 1341-1348.

SONG, M.; NOH, J. (2006). Best new product development and management practices in the Korean high-tech industry. Industrial Marketing Management. v. 35 , n. 3. p. 262-278.

TIAN, P.; ZENG, S. X.; TAM, C. M. (2007) Overcoming barriers to sustainable implementation of the ISO 9001 system. Managerial Auditing Journal. v. 22, n. 3. p. 244-254.

ULLAH, F.; TAYLOR, P. (2007) Are UK technology-based small firms still finance constrained? The International Entrepreneurship and Management Journal. v. 3 , n. 2, p. 189-203. 
INDEPENDENT JOURNAL OF MANAGEMENT \& PRODUCTION (IJM\&P)

http://www.ijmp.jor.br

v. 7, n. 1, January - March 2016

ISSN: 2236-269X

DOI: 10.14807/ijmp.v7i1.387

YAHYA, S.; GOH, W. (2001) Implementation of an ISO 9000 quality system, International Journal of Quality and Reliability Management, v. 18, n. 9 p. 941966. 